\title{
輸液中におけるウロキナーゼの安定性*1
}

\author{
村瀬勢津子, 関 京子, 竹内尚子, 朝長文弥 \\ 北里大学病院薬郕部*2
}

\section{Stability of Urokinase in Infusions Containing Other Drugs*1}

\author{
Setsuko Murase, Kyoko Seki, Hisako TAKeuchi, and Fumiya Tomonaga \\ Pharmacy, Kitasato University Hospital*2
}

(Received October 21, 1981)

Compatibility tests of Urokinase (UK) and Calcicol (CC), Persantin (PS), K.C.L., Nicholin (NC), Penbritin (ABPC), Celtol (CEC) and Keflin (KF) in 3 kinds of infusion were made in terms of measurement of $\mathrm{pH}$, observation of visible changes and residual potency of UK by fibrin-plate methods after mixture. The results were as follows : 1) Mixture of UK and K. C. L. or UK in infusions showed a remarkable decrease of the potency of UK respectively, which indicated that they are incompatible. 2) Mixture of UK and CC, PS, NC, ABPC and CEC did not show visible changes, and decrease of potency of UK was slow as compared with that in compatibility tests of those direct injections.

Keywords_urokinase ; infusion ; stability of urokinase ; mixture ; compatibility ; fibrin-plate method; residual potency; decrease of potency

\section{はじめに}

前報1)において, ウロキナーゼ(ミドリ十字, 以下 UK) と 39 種類の注射薬との 配合変化試験をそれぞれ 1 対 1 の配合量で検討し, その成績について報告した.

当院における UK の混合使用の実態調查 ${ }^{1)}$ で UK は 輸液類に混合されて用いられる頻度が非常に高かった. そこで今回, 前報で配合不適としたカルチュール（以下 CC), ペルサンチン (以下 PS), K. C. L., ニコリン (以下 $\mathrm{NC}$ ), ペンブリチン (以下 $\mathrm{ABPC}$ ), セルトー ル (以下 CEC) およびヶフリン (以下 $\mathrm{KF}$ ) について 輸液中に打ける安定性ならびに K. C. L. との混合によ り変化が起きる原因, またこれら7種類の注射薬と他社 製品のウロナーゼ（持田製薬, 以下 UR）との配合変化 についても併せて検討し, 若干の知見を得たのでその成 績を報告する。

*1 本報を「ウロキナーゼの配合変化に関する研究」 第 2 報とする. 第10回日本病院薬剤師会 関東学術 大会（千葉, 1980）で発表.

*2 相模原市北里 1丁目 15-1；15-1, Kitasato 1-chome, Sagamihara-shi, 228 Japan

\section{実 験 の 部}

\section{1. 実験材料}

実験材料を一括して Table 1 に示した. ウロキナー ゼ製剤は UK および UR のそれぞれ 6000 unit（以下 u）のものを実験に使用した. 配合剂は 2 剂配合時にお ける配合変化試験において外観変化の認められた CC $425 \mathrm{mg}, \mathrm{PS} 10 \mathrm{mg}$ を, また同様に力価の低下が認められ た K.C.L. $20 \mathrm{ml}$, NC 250mg, ABPC $1 \mathrm{~g}$, CEC $1 \mathrm{~g}$ および KF $1 \mathrm{~g}$ をそれぞれ用いた。輸液は当院で UK と混合頻度が高い $5 \%$ グルノン (以下 $\mathrm{GL}$ ), フィシザ ルッ (以下 $\mathrm{PZ}$ ) およびッリタ $\mathrm{T}_{3}$ (以下 $\mathrm{ST}_{3}$ )を, をた 試薬の塩化カリウム（以下 $\mathrm{KCl}$ ) 拈よびリン酸リボフ ラビンナトリウム (以下 SRP) をそれぞれ実験材料と した.

\section{U K および U R のカ価測定}

用時溶解の注射薬, すなわち UK および $\mathrm{KF}$ はそれ ぞれ $5 \mathrm{ml}$, UR および CEC は同様に $10 \mathrm{ml}, \mathrm{ABPC}$ は $20 \mathrm{ml}$ の生理食塩液 (以下生食) に溶解し，また $15 \%$ $\mathrm{KCl}$ および $0.06 \% \mathrm{SRP}$ 水溶液をそれぞれ調製し, 各 各試料液とした。この各試料液はそれぞれの割合に混合 
Table 1. Summary of Materials Investigated in Additive Combination Tested

\begin{tabular}{|c|c|c|c|c|c|}
\hline & Brand name & Ingredients & Amounts & Appearance & $\mathrm{pH}$ \\
\hline Urokinases & $\begin{array}{l}\text { Urokinase } \\
\text { Uronase }\end{array}$ & Urokinase & $\begin{array}{l}6000 u n 1 t / 5 \mathrm{ml} \\
6000 \text { unit/10ml }\end{array}$ & $\begin{array}{l}\text { colorless } \\
\text { colorless }\end{array}$ & $\begin{array}{l}7.0 \\
7.0\end{array}$ \\
\hline The other & $\begin{array}{l}\text { Calcicol } \\
\text { Persantin } \\
\text { K.C.I. } \\
\text { Nicholin }\end{array}$ & $\begin{array}{l}\text { Calium gluconate } \\
\text { Dipyridamol } \\
\text { Potassium chloride } \\
\text { Citicoline }\end{array}$ & $\begin{array}{l}425 \mathrm{mg} / 5 \mathrm{ml} \\
10 \mathrm{mg} / 2 \mathrm{ml} \\
20 \mathrm{ml} \\
250 \mathrm{mg} / 2 \mathrm{ml}\end{array}$ & $\begin{array}{l}\text { colorless } \\
\text { yellow } \\
\text { yellow } \\
\text { colorless }\end{array}$ & $\begin{array}{l}6.4 \\
2.8 \\
5.6 \\
7.3\end{array}$ \\
\hline Antibiotics & $\begin{array}{l}\text { Penbritin } \\
\text { Celtol } \\
\text { Keflin }\end{array}$ & $\begin{array}{l}\text { Sodium ampicillin } \\
\text { sodium cefacetrile } \\
\text { Sodium cefalotin }\end{array}$ & $\begin{array}{l}\mathrm{Ig} / 20 \mathrm{ml} \\
\mathrm{Ig} / 10 \mathrm{mI} \\
\mathrm{Ig} / 5 \mathrm{mI}\end{array}$ & $\begin{array}{l}\text { pale yellow } \\
\text { pale yellow } \\
\text { pale yellow }\end{array}$ & $\begin{array}{l}9.0 \\
4.6 \\
5.4\end{array}$ \\
\hline Infusions & $\begin{array}{l}\text { Glunon } \\
\text { Physisalz } \\
\text { Solita } \mathrm{T}_{3}\end{array}$ & $\begin{array}{l}\text { Glucose } \\
\text { Isotonic sodium chloride } \\
\text { compaunds }\end{array}$ & $\begin{array}{l}500 \mathrm{ml}(5 \%) \\
500 \mathrm{ml} \\
500 \mathrm{ml}\end{array}$ & $\begin{array}{l}\text { colorless } \\
\text { colorless } \\
\text { colorless }\end{array}$ & $\begin{array}{l}4.4 \\
5.6 \\
5.1\end{array}$ \\
\hline
\end{tabular}

Powder for injection dissolved isotonic sodium chloride solution respectively.

し，各混合試料原液とした。また輸液中の安定性試験で は，各輸液に配合剂を加えた後，最後にUKを各々混合 し, 各輸液の混合試料液としてそれぞれ実験に用いた。 なお実験はすべて $1 / 5$ または $1 / 10$ 量のスケールで行っ た.

力価の測定は Walton ${ }^{2,3,4)}$ らの方法に準じたヒト・ト ロンビンおよびヒト・フィブリノーゲンを用いたフィブ リン平板法 (以下 FP 法) で前報と同様にして行った. すなわち，各々混合試料原液または混合試料液はいずれ 子室温に放置し, 配合直後, 3,6 および24時間後にそ れぞれサンプリングし，必要に応じて生食で推定 40〜 $20 \mathrm{u} / \mathrm{ml}$ の範囲に入るように希䣋した後, その $10 \mu 1$ を各 平板に添着させ, $37^{\circ} \mathrm{C}, 20$ 時間培養した. 培盖後, 溶 解空を測定した。 また標準液を用いて $50 \sim 6.25 \mathrm{u} / \mathrm{ml}$ 範 囲で検量線を作成し，これょり UK および UR の力価 を算出した。 なおいずれの測定も 2 枚の平板を用い， 1 試料に対して 6 点を添着させ, 成績はその平均値で示し た.

\section{K. C . L . の各配合吾に対するU K の安定性}

K.C.L. $4 \mathrm{ml} ， 2 \mathrm{ml}$ および $1 \mathrm{ml}$ に UKの試料液をそ

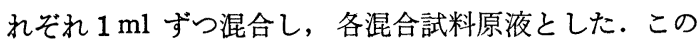
各混合試料原液を室温飞放置して24時間経時的にサンプ リングし，前報と同様にして UK の力価を FP 法で測 定した.

\section{4. 輸液中における U Kの安定性}

$5 \% \mathrm{GL}, \mathrm{PZ}$ および $\mathrm{ST}_{3}$ の各々 $50 \mathrm{ml} ゙$ つっったメ スフラスコに各配合剂 $1 / 5$ 量の試料液, すなわち CC 1 $\mathrm{ml}$, PS $0.4 \mathrm{ml}$, K.C.L. $4 \mathrm{ml}$, NC $0.4 \mathrm{ml}$, ABPC 4 $\mathrm{ml}, \mathrm{CEC} 2 \mathrm{ml}$ および $\mathrm{KF} 0.25 \mathrm{ml}(50 \mathrm{mg})$ をそれぞれ 加え, 最後に UK を $1 \mathrm{ml}$ ずつ加えて混合し, 各混合試
料液とした。この混合試料液を室温に放置し， 24 時間 経時的にサンプリングし，同様にして $\mathrm{pH}$ の測定，外観 変化の有無の観察および同様に力価の測定をそれぞれ行 った.

なお，CC および PS との混合では， 2 剂配合の試験 でUK の力価に低下がみられなかったことから力価の測 定は省略した。

\section{K. C . L . の添加剂のU Kにおよぼす影響}

K.C.L. 中の成分である $\mathrm{KCl}$ および SRP を試薬特 級を用いて，15\% および $0.06 \%$ 水溶液をそれぞれ調製 した。この $15 \% \mathrm{KCl}$ 溶液 $4 \mathrm{ml}$ および $0.06 \% \mathrm{SRP}$ 溶液 $4 \mathrm{ml}$ を UK $1 \mathrm{ml}$ にそれぞれ混合し，各混合試料 原液とした。この混合試料原液を室温に放置し，24時間 経時的にサンプリングし，同様にしてUK の力価を測定 した.

\section{U KとU Rの配合変化における比較}

UK の 2 剂配合時の配合変化試験において, 配合直後 から 3 時間の間で変化を起こした注射薬, すなわち CC $1 \mathrm{ml}$, PS $0.4 \mathrm{ml}$, K.C.L. $4 \mathrm{ml}$, NC $0.4 \mathrm{ml}, \mathrm{ABPC} 4$ $\mathrm{ml}, \mathrm{CEC} 2 \mathrm{ml}$ および $\mathrm{KF} 1 \mathrm{ml}$ の各試料液を UR 2 $\mathrm{ml}$ の試料液に各々混合し各混合試料原液とし, この混 合試料原液をUK の試験と同様に室温飞放置して 24 時 間経時的にサンプリングし, $\mathrm{pH}$ 湘定, 外観变化の有無 の観察および力価の測定をそれぞれ行った。

\section{実 験 結 果}

\section{K. C . L . の各配合量に対するU Kの安定性}

K. C. L. の各配合量の混合試料原液をそれぞれ推定 40 30u/ $\mathrm{ml}$ になるように生食で希釈した後, 各々の 10 $\mu 1$ を各平板にそれぞれ添着させて，UK の力価を測定し 
た結果を Fig. 1 と示した.

K.C.L. の配合量 $4 \mathrm{ml}, 2 \mathrm{ml}$ および $1 \mathrm{ml}$ のいずれ も配合直後は 103 92\%であった。 しかし配合 3 時間後 から力価は 59 41\% と著しく低下し, 経時的にも变化
が認められ，配合 24 時間後には $31 〜 22 \%$ であった。

\section{2. 輸液中における U K の安定性}

輸液の各混合試料液について, $\mathrm{pH}$ の測定および外観 变化の有無の観察を行い，また力価は各輸夜の混合試料

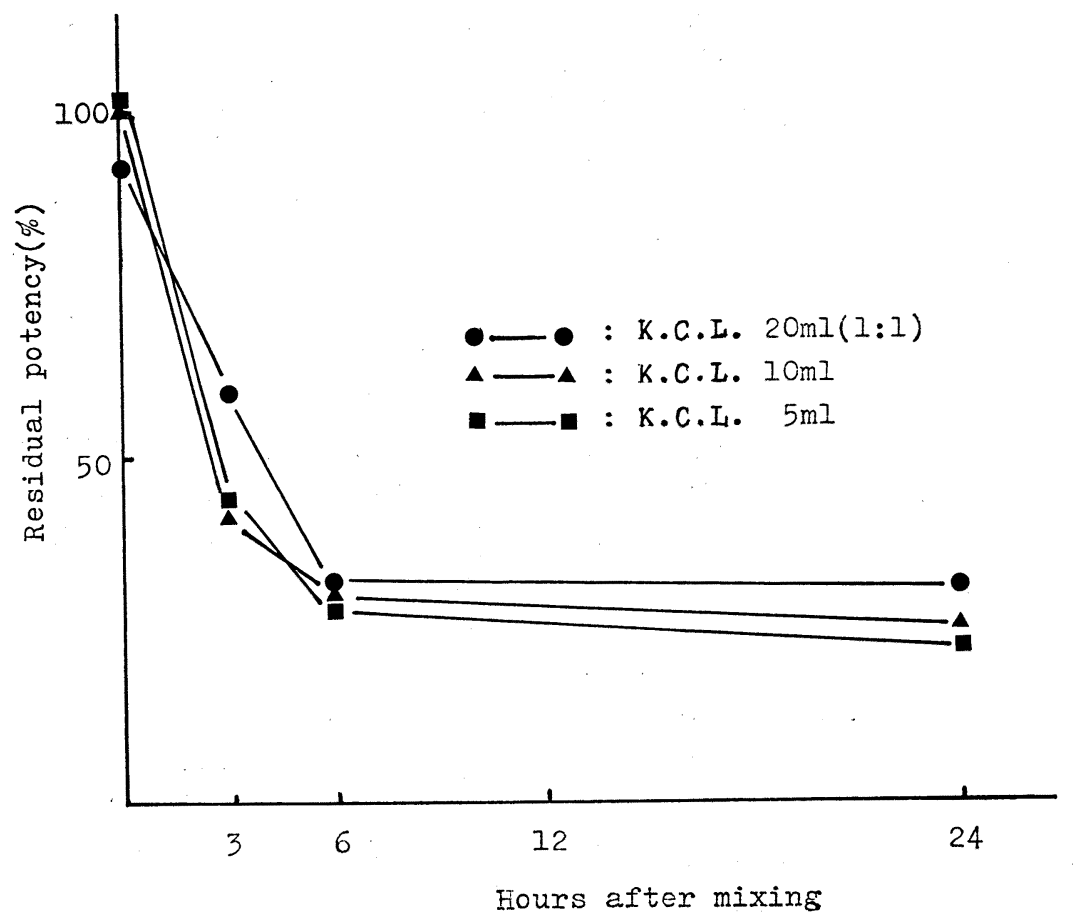

Fig. 1. Stability of Urokinase at Various Mixed Amounts of K.C.L. 6000 units of Urokinase was mixed in $20 \mathrm{ml}, 10 \mathrm{ml}$ and $5 \mathrm{ml}$ of K.C.L. respectively

液の $10 \mu 1$ ずつを平板に添着させて同様にして FP 法で 測定した。その $\mathrm{pH}$ 測定および外観変化の 有無の観察の 結果を Table 2 に，また力価の測定の結果を Fig. 2 〜6 に示した.

$\mathrm{pH}$ においては, ABPC, CEC および KF では GLお よび PZ 中で, 経時的に酸性側へのシフトが見られた他 はすべて配合直後の $\mathrm{pH}$ に近似值を示した。 また，2剂 混合時において, 配合直後から濁度および沈殿の外観変 化のみられた CC および PS は輸腋中の希釈された状 態では, ほとんどその変化は認められず, 配合24時間後 もとの変化は見られなかった。

$\mathrm{CEC}$ との混合では， $\mathrm{ST}_{3}$ 中において配合 24 時間後に 淡桃色の着色変化が, KF との混合では, 着色および濃 色变化がそれぞれ見られた (Table 2).

力価に怙いて, K.C.L. との混合で $\mathrm{ST}_{3}$ 中では配合
直後に $95 \%$ ，配合 3 時間後では $78 \% ， 6$ 時間後は $63 \%$ の残存率をそれぞれ示し，その低下は 2 剂配合時の 92 \%，59\%和よび $32 \%$ に比較してやや緩慢であった。ま た GL および $\mathrm{PZ}$ 中では 2 版配合時とほぼ同様の低下 を示した (Fig. 2).

$\mathrm{NC}$ との混合では, GL 中で配合 24 時間後も $90 \%$ 前 後の残存力価を示し安定で，また $\mathrm{PZ}$ 中では配合 6 時間 後まで $80 \%$ 以上の残存率を示し，その減少は比較的緩 慢であった。しかし $\mathrm{ST}_{3}$ 中では配合直後に $97 \%$ ，配合 6 時間後では $72 \%$ と経時的に減少がみられ，配合 24 時 間後は残存率 $34 \%$ であった (Fig.3).

ABPC では，2剂配合の試験において配合直後に 57 \%と著しい力価の低下を示したのに対し，GL および $\mathrm{PZ}$ 中では配合 6 時間後も $90 \%$ 以上の残存力価を示し 安定であった。また $\mathrm{ST}_{3}$ 中でも配合 24 時間後まで $80 \%$ 
Table 2. Results of Compatibility Tests with Urokinase and Seven Kinds of Injection in Infusions for $\mathrm{pH}$ and Appearance

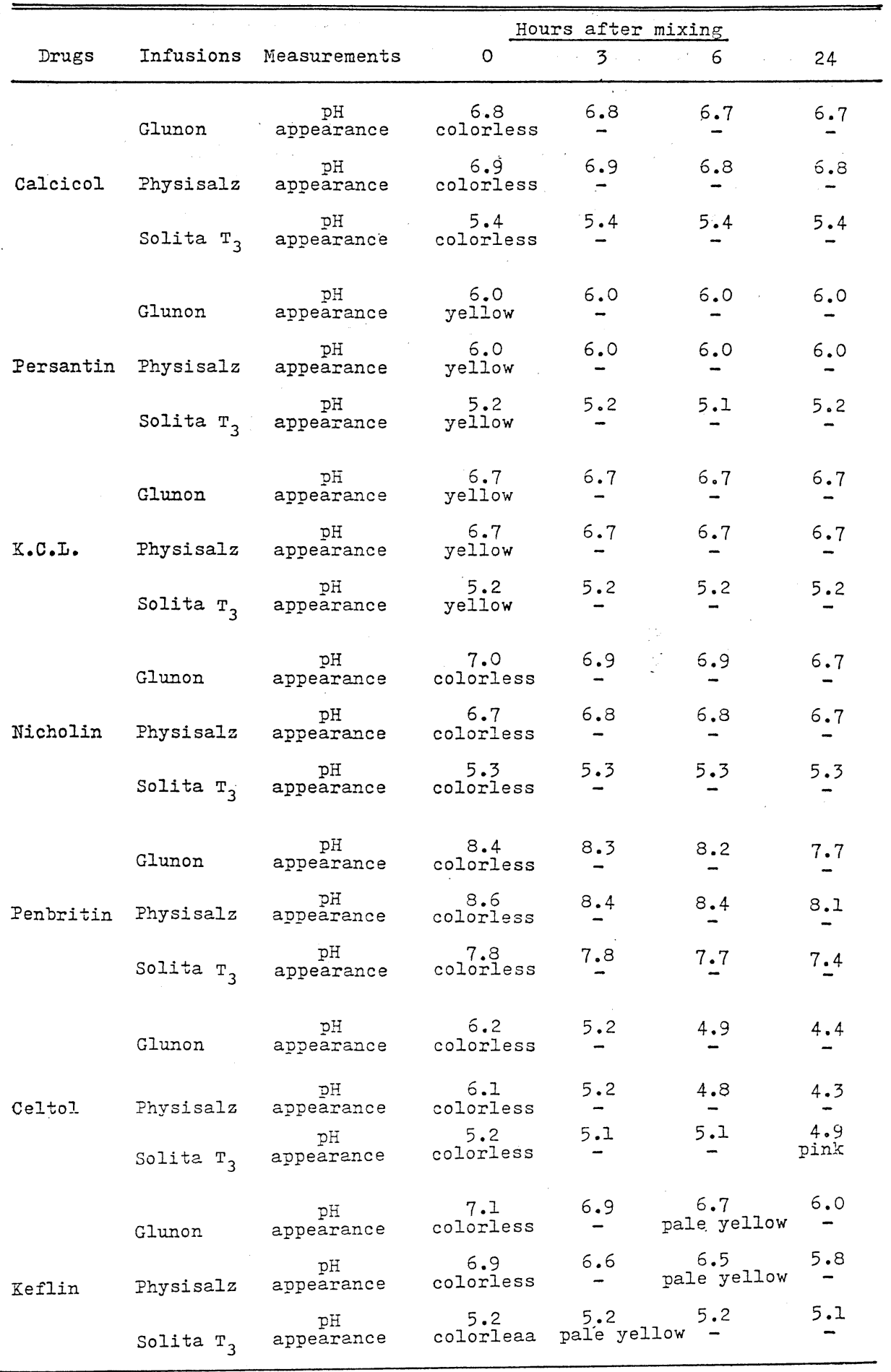


以上の残存率を示し比較的安定であった (Fig. 4).

CEC との混合では，2 剤配合の試験で配合直後に 85 \%と力価の低下が見られ，配合 24 時間後には $45 \%$ の残 存率であった．各輸液中では配合 3 時間後まで $80 \%$ 以 上を示し， 2 剂配合に 比較してその低下は緩慢であっ た.しかし配合 6 時間以降はいずれも 2 剂配合の場合よ りさらに著しい力価の低下が見られた (Fig. 5).

$\mathrm{KF}$ との混合では，KF の配合量を 2 剂配合時の配合 変化試験とおける量すなおち $1 \mathrm{~g}$ から $250 \mathrm{mg}$ に減じて
混和し，混合試料液とし用いた． 2 剂配合の配合直後に おける残存率 $40 \%$ に比較し，輸液中では 85〜 65\% でそ の低下は緩和された。しかし配合 3 時間から 6 時間後に は，いずれる残存率 50\%以下であった (Fig. 6).

KF の配合量がこれより増加すれば，さらに力価の低 下は著しくなると思われる。

\section{K. C . L . の添加剂のU Kにおよぼす影響}

$15 \% \mathrm{KCl}$ 溶液および $0.06 \% \mathrm{SRP}$ 溶液に UK をそれ ぞれ混合し，混合試料原液として用いた。この原液を推

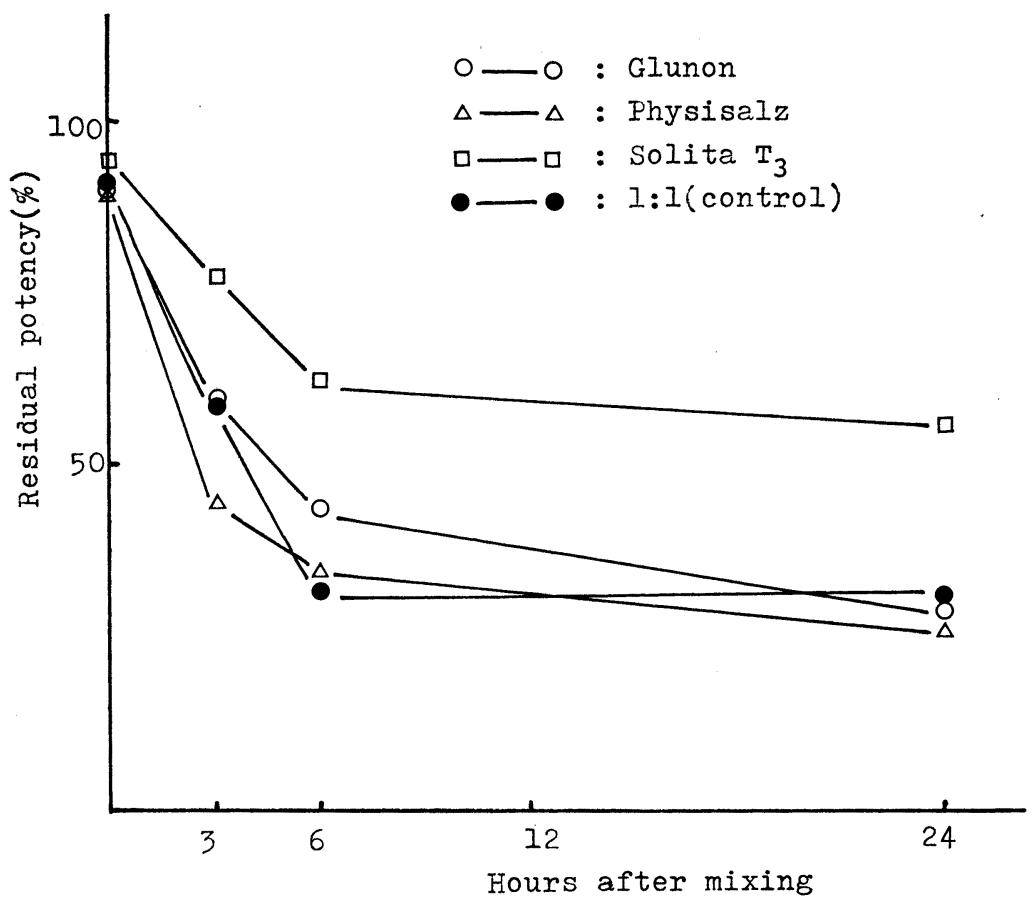

Fig. 2. Stability of Urokinase in Infusions Containing K.C.L. 12000 units of Urokinase was mixed in $500 \mathrm{ml}$ of infusions containing $40 \mathrm{ml}$ of K.C.L.

定 $30 \mathrm{u} / \mathrm{ml}$ になるように生食で希釈した後，その $10 \mu 1$ ずつを平板に 各々添着し，同様にして UK の力価の測 定を行った。 その結果, $\mathrm{KCl}$ との混合では配合 3 時間 後も $90 \%$ 以上の力価を示すのに対し, SRP との混合で は配合 3 時間後残存率 $34 \%$ と著しい力価の低下を示し, 配合 24 時間後はわずか $10 \%$ 以下であった (Fig. 7).

\section{U KとU Rの配合変化における比較}

UR そ CC, PS, K. C. L., NC, ABPC, CEC およ び $\mathrm{KF}$ との 2 剂配合時の配合変化試験を UK の場合と 同様に行った．その結果, $\mathrm{pH}$ の測定および外観変化の
有無の観察を Table 3 に, また力価の測定を Fig. 8, 9 と示した.

pH そおいて，UK との混合では ABPC，CEC および $\mathrm{KF}$ に，経時的に酸性側ヘシフトが見られ，UR におい ても同様の傾向であった.

外観に打いて，CC および PS では UK との混合で 直後より外観変化が認められたが, UR では外観変化は 配合 24 時間後も見られなかった (Table 3).

力価において, K.C.L., NC および KF との混合で は，UR は UK の場合とほぼ同様の低下を示した。し 


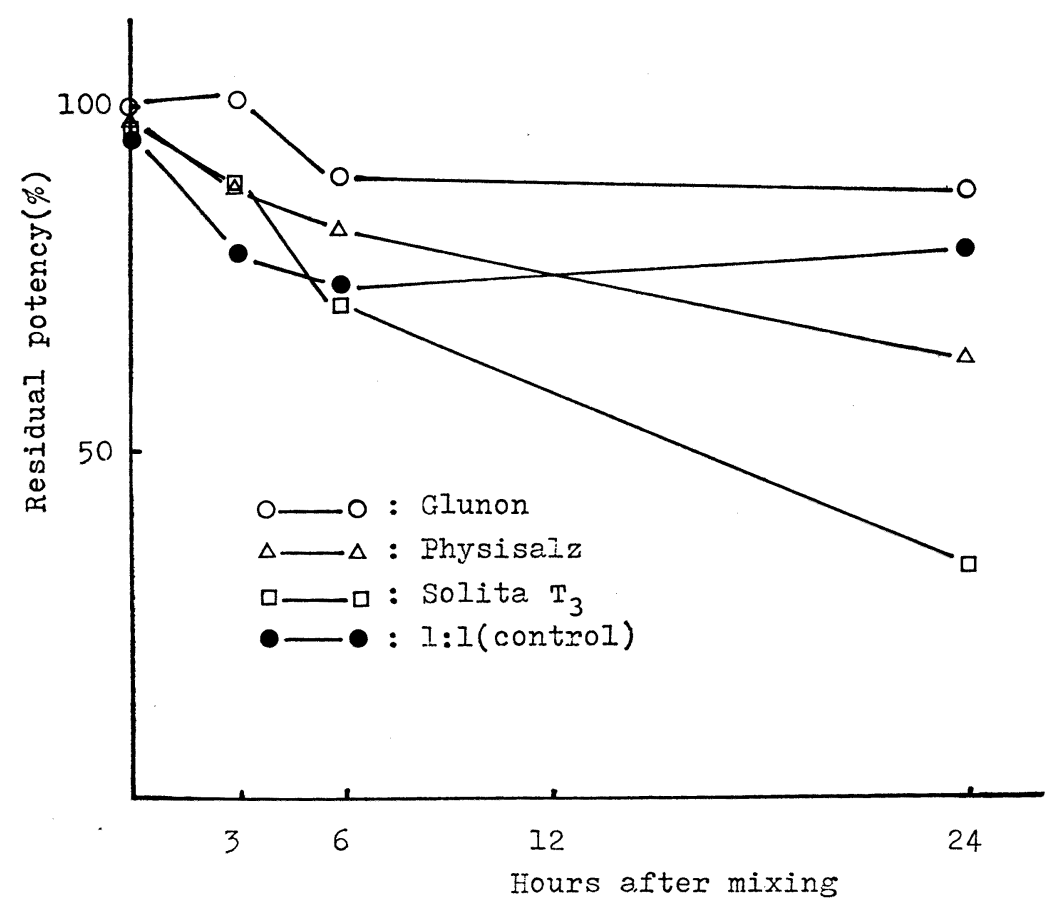

Fig. 3. Stability of Urokinase in Infusions Containing Nicholin 12000 units of Urokinasse was mixed in $500 \mathrm{ml}$ of infusions containing $500 \mathrm{mg}$ of Nicholin

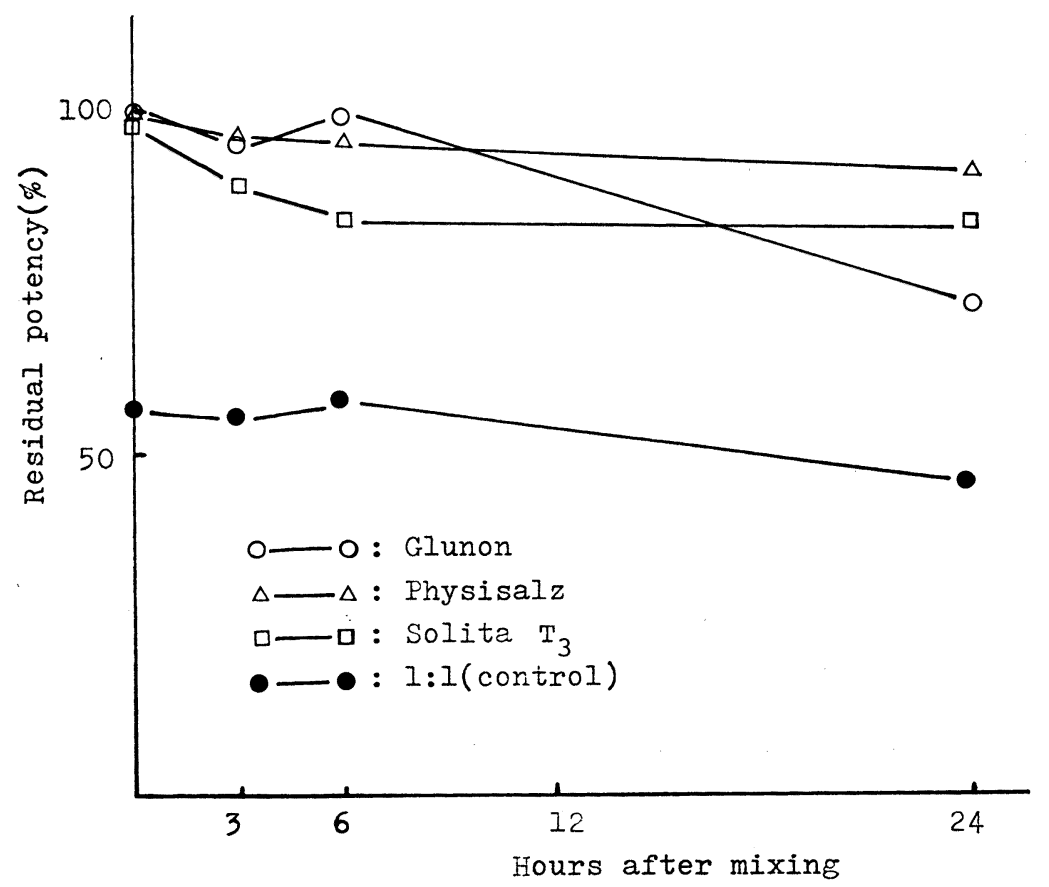

Fig. 4. Stability of Urokinase in Infusions Containing Penbritin 12000 units of Urokinase was mixed in $500 \mathrm{ml}$ of infusions containing $2 \mathrm{~g}$ of Penbritin 


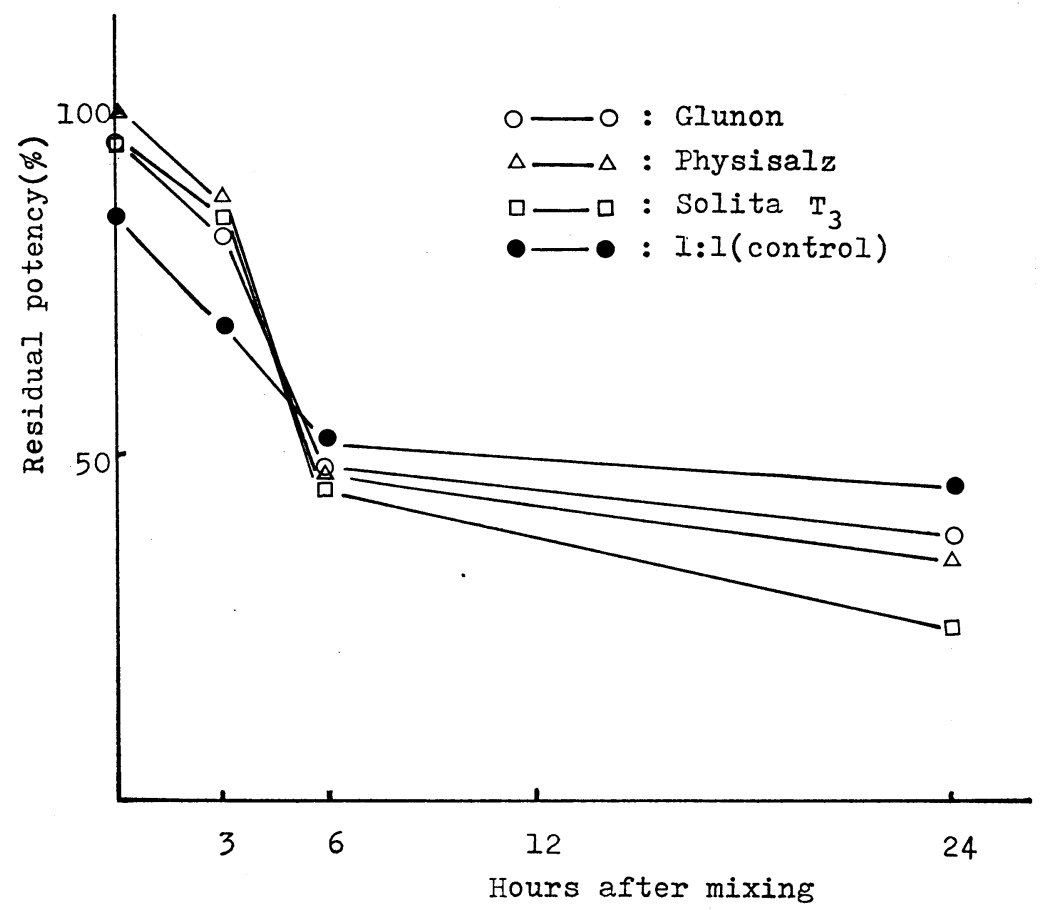

Fig. 5. Stability of Urokinase in Infusions Containing Celtol 12000 units of Urokinase was mixed in $500 \mathrm{ml}$ of infusions containing $2 \mathrm{~g}$ of Celtol

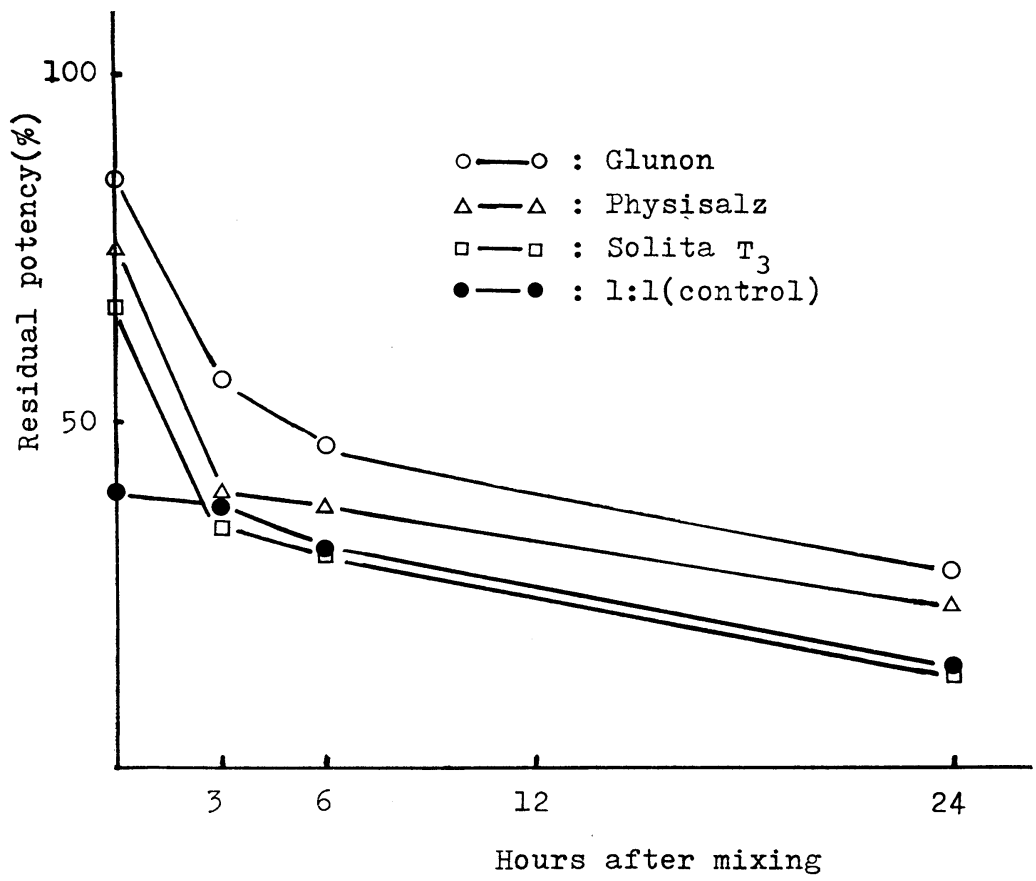

Fig. 6. Stability of Urokinase in Infusions Containing Keflin 12000 units of Urokinase was mixed in $500 \mathrm{ml}$ of infusions containing $250 \mathrm{mg}$ of Keflin 


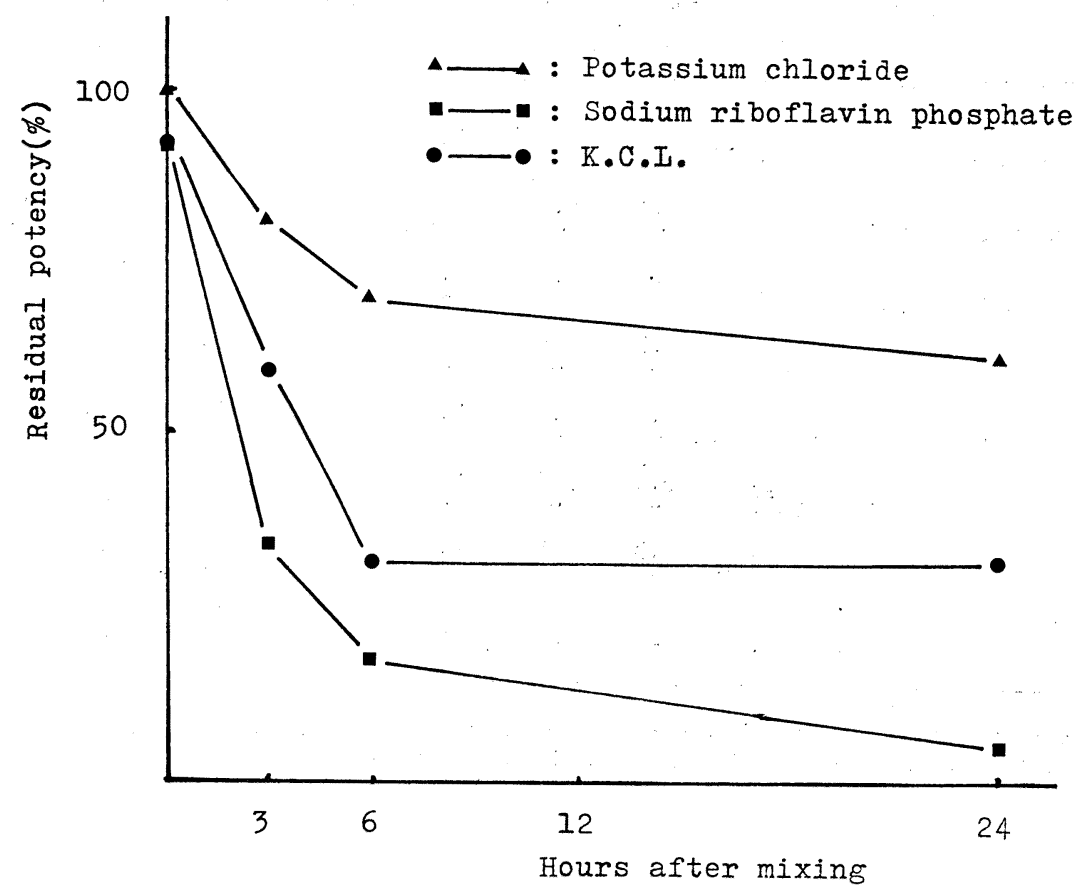

Fig. 7. Influence of Additives

6000 units of Urokinase was mixed in $20 \mathrm{ml}(15 \%)$ of K.C.L., $20 \mathrm{ml}(15 \%)$ of potassium chloride and $20 \mathrm{ml}$ $(0.06 \%)$ of sodium riboflavin phosphate respectively

かし UK と ABPC との混合では配合直後より $57 \%$ と 著明な力価の低下を示したのに対し，UR との混合では 配合 24 時間後も $90 \%$ 前後の残存率を示し，比較的安定 であった．CEC において，配合直後の力価は 103\%を 示し, UK の $85 \%$ に比較して高い残存率であった。 し かし経時的には UK の 69 45\% に比較して UR では 53〜29\% と力価の低下が見られた（Fig. 8，9).

\section{考察}

CC および PS は，UK との 2 剂配合で配合直後より 濁度や沈殿の外観変化が見られたのに対し，輸液中では その変化が見られなかった。このことは混合方法により 外観変化を起こす可能性があり, 混合使用する際は混合 順序などに十分に留意する必要があると思われる。

K.C.L. との混合では，2剂配合および輸液中の希釈 された状態でも K.C.L. の配合量に関係なく，配合 3 時間後より約 $50 \%$ 前後の低下が認められた， $\mathrm{KCl}$ との 配合試験江おいて，配合 3 時間後で $90 \%$ 以上の 残存率 を示し，配合 6 時間後に $70 \%$ ，配合 24 時間後には $61 \%$ とその後の低下は比較的緩慢であった。しかし SRP と
の混合では, 配合 3 時間後に残存率 $34 \%$ に, 配合 24 時 間後にはわずか $10 \%$ 以下であった。このことば主薬で 西る $\mathrm{KCl}$ より添加剤である $\mathrm{SRP}$ の方がウロキナーゼ 活性に拉よぼす影響がより大きいことを示唆して抢り， 低下の原因になっていると思われる。

UK と UR との配合変化試験の比較では, UR と K. C.L., NC, CEC および KF との混合は, UK の結果 と同様の傾向を示した. しかし UK と ABPC の混合で は配合直後より約 $50 \%$ と著明な力価の 低下を 示したの に対し，UR では配合 24 時間後も $90 \%$ 前後の残存率を 示し比較的安定であった.この相違はウロキナーゼ製剤 中の添加物の影響によるものと思われる.

また UR と K.C.L., NC, CEC および KF との混 合では UK と同様の傾向を示したことから，これはウ ロキナーゼ自身に配合剤の主薬または添加剤が作用し， ウロキナーゼ活性汇影響をおよぼしたものと思われる。

今回検索した CC, PS, K. C. L., NC, CEC および $\mathrm{KF}$ のそれぞれ含まれた 3 種の輸液中での UR の安定 性については，UR の配合試験の成績がほぼ適用できる と思われる。 
Table 3. Comparison between Compatibility Tests with Urokinase and Uronase for $\mathrm{pH}$ and Appearance

\begin{tabular}{|c|c|c|c|c|c|c|c|c|c|}
\hline \multirow[b]{2}{*}{ Drugs } & \multirow[b]{2}{*}{ Measurements } & \multicolumn{4}{|c|}{$\frac{\text { Urokinase }}{\text { Hours after mixing }}$} & \multicolumn{4}{|c|}{ Uronase } \\
\hline & & 0 & 3 & 6 & 24 & 0 & 3 & 6 & 24 \\
\hline Calcicol & $\begin{array}{c}\mathrm{pH} \\
\text { appearance }\end{array}$ & white turbidity & 6.3 & $\underline{6.3}$ & $\begin{array}{l}6.3 \\
\text { precipitation }\end{array}$ & $\begin{array}{l}6.6 \\
\text { colorless }\end{array}$ & 6.5 & 6.6 & 6.5 \\
\hline Persantin & $\begin{array}{c}\mathrm{pH} \\
\text { appearance }\end{array}$ & $\begin{array}{c}4.8 \\
\text { yellow tuxbidity }\end{array}$ & 4.8 & 4.8 & 4.6 & $\begin{array}{c}3.5 \\
\text { yeliow }\end{array}$ & 3.5 & 3.4 & 3.5 \\
\hline K.C.I. & $\begin{array}{c}\text { pH } \\
\text { appearance }\end{array}$ & $\begin{array}{c}6.5 \\
\text { yeliow }\end{array}$ & 6.5 & 6.5 & 6.5 & yeliow & 6.2 & 6.3 & $\underline{6.3}$ \\
\hline Micholin & $\begin{array}{c}\text { pH } \\
\text { appearance }\end{array}$ & $\begin{array}{l}7.0 \\
\text { colorless }\end{array}$ & 7.0 & 7.0 & 7.0 & coloriless & 7.0 & 7.0 & 7.0 \\
\hline Penbritin & $\stackrel{\mathrm{pH}}{\text { appearance }}$ & pale yeliow & 9.0 & 9.0 & 8.3 & pale yellow & 8.5 & 8.4 & 8.3 \\
\hline Celtol & $\begin{array}{c}\mathrm{pH} \\
\text { appearance }\end{array}$ & pale yeliow & 5.5 & -5 & 4.5 & pale yellow & 4.6 & 4.5 & 4.2 \\
\hline Keflin & $\begin{array}{c}\mathrm{pH} \\
\text { appearance }\end{array}$ & pale yeliow & 6.5 & 6.0 & $\begin{array}{l}5.0 \\
\text { yeliow }\end{array}$ & pale yellow & $\stackrel{5.0}{-}$ & 4.7 & 4.4 \\
\hline
\end{tabular}

6000 unit of Urokinase and Uronase were mixed in $425 \mathrm{mg}$ of Calcicol, 10mg of Persantin $250 \mathrm{mg}$ of Nicholin, 20ml of K.C.L., Ig of Penbritin, Ig of Celtol and Ig of Keflin respectivery.

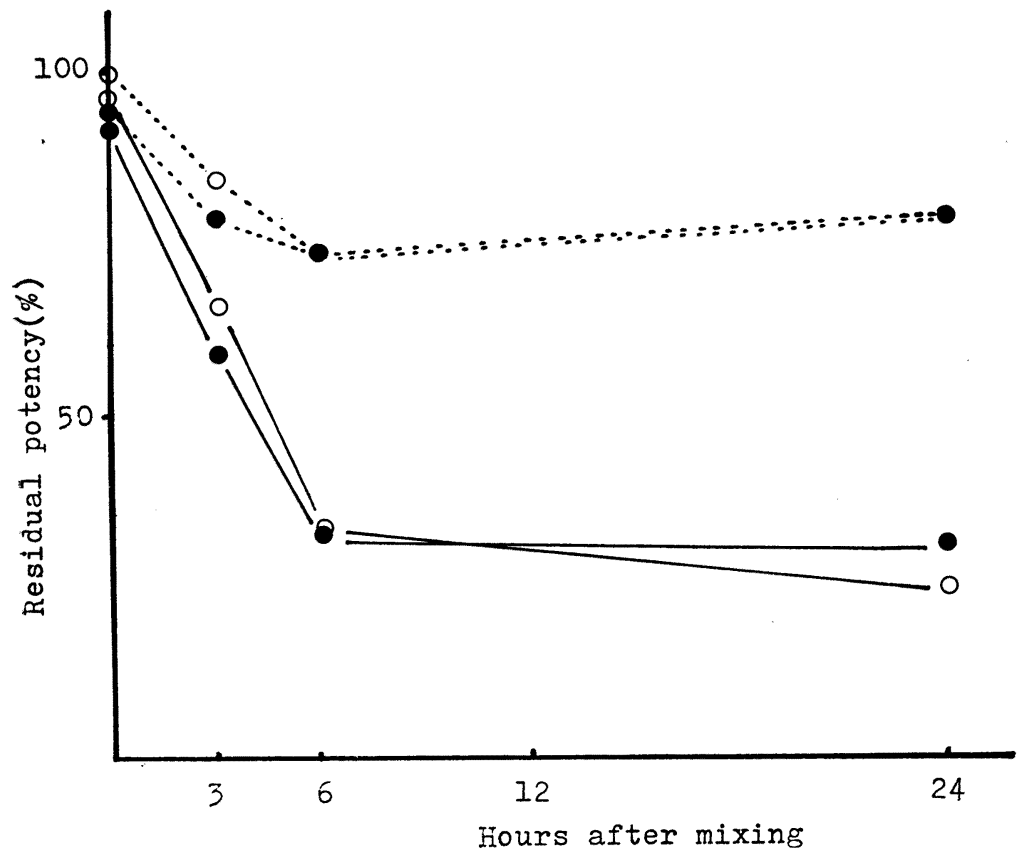

Fig. 8. Comparison between Compatibility Tests with Urokinase and Uronase in K.C.L. and Nicholin

$\ldots$ : Urokinase $\quad$ - K.C.L.
$\ldots$ : Uronase $\quad \ldots \ldots$ : Nicholin 


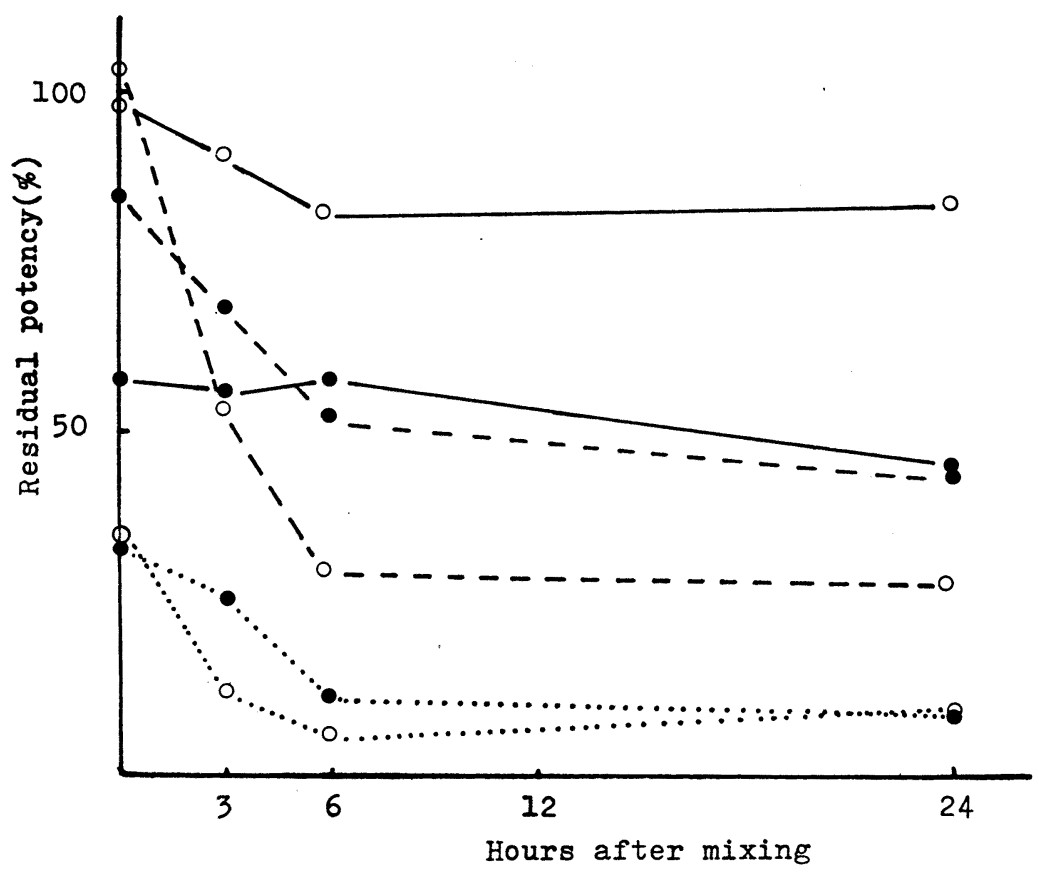

Fig. 9. Comparison between Compatibility Tests with Urokinase and Uronase in Penbritin, Celtol and Keflin

$$
\begin{aligned}
& \Leftrightarrow \text { : Urokinase } . . . \text { : Celtol }
\end{aligned}
$$

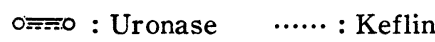

$$
\begin{aligned}
& \text { - Penbritin }
\end{aligned}
$$

\section{結部}

以上輸液中で, ウロキナーゼとカルチュール, ペルサ ンチン, K.C.L., ニコリン, ペンブリチン, セルトー ルおよびヶフリンの配合変化を検討した結果, K.C.L. およびヶフリンは輸夜中に怙いても著明な力価の低下が 見られたことから，直接の混合使用は避けるべきであ る.

カルチュールおよびペルサンチンは 2 版配合で外観変 化が見られたが, 輸夜中ではその変化が見られなかった こと, またニコリン, ペンブリチンおよびセルトールで は 2 剤配合と比較して, 輸液中では力価の低下は比較的 緩慢であるものの長時間におよんだ場合はやはり著明な
低下が見られることから，これらの混合使用は注入時間 に十分に留意することが望ましいと思われる。

\section{交献}

1）村瀬勢津子, 遠山啓子, 関 京子, 加賀谷肇, 朝 長交弥, 中川輝昭: 病院薬学, $8(3), 192$ (1982).

2) P.L. Walton : Clin. Chim. Acta, 13 (5), 680 (1966).

3) N.A. Marsh : Thromb. Diath. Hoemr., 31, 75 (1972).

4）西崎笹夫, 川村次良：医薬品研究，5 (3)，295 (1974). 